\title{
Perceptions of The Primary Stakeholders on Fisheries Information Services in Kerala State: An Evaluation Study
}

\author{
M JAYAPRADEEP* \\ DR R RAMAN NAIR**
}

Fishery sector occupies a crucial place in the socio-economic development of the State of Kerala. Though Kerala boasts of the highest quality of life, the State's fishing community continues to lag behind-socially and economically. Fisheries is a specialized field wherein the information, an ingredient and a problem-solving tool, is a key factor for transformation of the sector. Speedy and effective exploitation of the knowledge acquired in the sector has to be applied in education, research, development and extension activities for the sustainable development of the sector. The State has adequate information resources but they are not optimally utilized by the primary stakeholders of the sector due to inadequate ICT based service systems, LIS professionalism and proper understanding of the community's information needs. An assessment of the user perceptions on resources, services and needs of the sector shall entail for the improvement of the services and resources key to their needs and shall offer the opportunity to provide the right resource at the right time in right ways. An information system exclusive to the fisheries shall only be able to consolidate, integrate, and deliver the results in a cohesive, cooperative, resource sharing and network mode.

Keywords: Fisheries Information Services; Fisheries Information System; Fisheries Libraries; Fishery Primary stakeholders.

\section{INTRODUCTION}

Fishing remained an important human activity for livelihood and sustenance during the last 90,000 years (from Paleolithic period). ${ }^{1}$ Traditionally, fishing has been the principal avocation for the livelihood of a segment of the population living in the coastal region, and on the

* Kerala University of Fisheries and Ocean Studies, Panangad-PO, Kochi-682506. (Research Scholar, Karpagam University, Coimbatore).

E-mail:mjayapradeep@gmail.com.

** SDO, Capital Centre, Central University of Kerala, Trivandrum-695043.

E-mail: ramannair.r@gmail.com. 
banks of rivers, lakes and canals. ${ }^{2}$ In India, post-independence era heralded organized development of the fisheries sector with a novel macro-economic support through succession of five-year plans and establishment of chains of national and state level institutions catering to fisheries research and development. ${ }^{3}$

In spite of the development of the fisheries sector, the fishing community occupies a low status in the society. Several factors such as low social status, poor economic conditions, illiteracy, leaning on middlemen, traditional fishing equipments and methods of fishing, low production rate and income influence the socio-economic conditions of fishermen. Therefore, socio-economic advancement of fishermen is essential for the proper development of the fishing industry in India.

\section{FISHING COMMUNITY AND INFORMATION FLOW}

Flow of information and knowledge in a society is the prerequisite for the sustainable socio-economic development. Fishing and fish farming communities are no exception. Traditionally, large numbers of women are involved in fish marketing in all the maritime states of India. They are active in both artisanal fisheries and the commercial fishery sector and contribute substantially to both national and household food security. Opportunities for women in fisheries could be enlarged in the field of integrated aquaculture, marketing and export as well as in research and technology development. ${ }^{4}$ These opportunities have to be heightened further through exchange of information and sharing of knowledge.

\section{NATIONAL INITIATIVES}

The potential and prospects of fisheries and aquaculture development in the country has initiated formulation of the National Policy on Aquaculture Development with clear objectives and priorities in the sector. The Development Plan identified the constraints for aquaculture development as weak flow of information, lack of technology transfer facilities and technology packages; and underpinned the need to strengthen fisheries information sector in the country. ${ }^{5}$

'Scheme on strengthening of Database and Information Networking for the Fisheries Sector' is a Central scheme to improve the database of inland and marine fisheries resources and catch of fish in India. The scheme proposes to adopt standardized methodology of data collection and aims to improve Information Technology System in the States/UTs as well as National level fishery institutes so that data collection and their analysis can be made efficient and effective. ${ }^{6}$ 


\section{THE STATE OF KERALA AND FISHERIES SECTOR}

Kerala, situated in the Southwest part of India, has a slender stretch of land with a long surf beaten coast on the western side and a lush green mountain range on the eastern side. The state has a coastline of $590 \mathrm{~km}$ and the Exclusive Economic Zone (EEZ) extending up to 200 nautical miles far beyond the continental shelf, which covers an area of $218536 \mathrm{sq} \mathrm{km}$ providing opportunities in traditional fishing in inshore waters. ${ }^{7}$

Fishery sector occupies an important place in the socio-economic development of the State of Kerala. About 3 per cent of the economy is attributable to Fisheries. The marine resource potential of the State within the continental shelf area is 7.5 lakh focus. The inland sector is endowed with extensive inter-connected brackishwater lakes and estuaries with a total area of 1,26,366 ha. Three east flowing and 41 west flowing rivers have a total length of $320 \mathrm{~km}$ and water spread area of 85000 ha. Reservoirs and minor irrigation tanks constitute 45725 ha. Tanks and Ponds have an area of 24310 ha. $^{8}$

As per statistics of the Department of Fisheries, there are 181015 active marine fishers, 54738 active inland fishers including women. They constitute $21 \%$ of fishermen population in Kerala. There are 113 Inland Fisheries Villages and 222 Marine Villages in Kerala. ${ }^{9}$ It is a source of livelihood to the people engaged fully, partially or in subsidiary activities pertaining to the sector, with an equally impressive segment of the population engaged in ancillary activities associated with fisheries and aquaculture. The fisheries industry includes culture, capture and postharvest handling, marketing and processing of fisheries products and involves the freshwater, brackish water and marine water resources.

The three estates of the fishery economy, viz the water resources, the fish resources and the human resources are at a comfortable position in Kerala. Kerala boasts of the highest quality of life in the country as measured by human development indicators. However, the State's fishing community has largely been left out of the general development experience. Traditional fisher folk who had no other employment option suffered and as a community, they continue to lag behind the other groups in the State in all areas of development, despite various programmes by the government and Fisheries Department for the up-liftment and welfare of the fisher folk. ${ }^{10}$

\section{STATUS OF FISHERIES INFORMATION}

Fisheries research conducted at various research institutions under 
Union and State Government at huge public expense come out with knowledge that can improve the sector. In addition, allied companies, fisheries co-operatives, certification agencies, water resource development agencies, planning and administration agencies, market and price commissions, export agencies, development boards, NGOs and others engaged in production, processing, etc. also disseminate information relevant to fisheries sector. Although the information and communication management has been in the agenda of premier agencies for planning, development and research, there is no easy availability of fisheries information from any system, be it Matsya Bhavan in Panchayat level or specialized institutions or ICAR system. The scenario is far from satisfactory for the primary stakeholders for whom the institutions are operated with huge investments.

\section{LITERATURE REVIEW}

\section{LITERATURE REVIEW}

Literature review on the subject revealed that the necessity of a wellstructured National System for Fisheries Data, Statistics and Information has been realized over the years and the subject discussed in several forums, a comprehensive information base is not yet formed and operated in the country. Information services provided by these institutions are feeble and the information bases are dispersed over institutions in the country. They are also not construed to meet information requirements of the primary stakeholders of fisheries sector.

\section{NEED AND IMPORTANCE OF THE STUDY}

Fisheries encompass a variety of sectoral spheres such as sociotechno-economic that are to be considered for systematic management, involving management of natural resources, human resources and a variety of infrastructural installations and establishments. ${ }^{11}$ Fishery Science is a multi-disciplinary, multi-faceted and applied branch of knowledge. Thus, knowledge and entrepreneurship shall be the decisive factors for the development of the sector. An assessment of the perceptions of the primary stakeholders on the information support systems and services in fisheries sector shall help in prospecting viable measures for the equitable distribution of information in fisheries sector.

\section{STATEMENT OF THE PROBLEM}

Mechanisms for exchanging information at regional level and ensuring its use by the primary stakeholders need systematic study. The 
development and good management of fisheries is generally the result of the quality of information, research and statistics generated in the sector. Vis-à-vis, information systems and services develop in response to the needs and activities of the stake holders. However, innovative information services targeting the primary stakeholders are few in fisheries sector. Lack of access to information is a significant barrier in the sector.

\section{OBJECTIVES OF THE STUDY}

Assessment of the existing services with regard to the needs of primary stakeholders with the objective of evolving proposals for further improvements in the fisheries information system and services presently rendered to them.

\section{METHODOLOGY}

Mixed methods of survey such as questionnaire, interview and field visits were applied to collect data from respondents. Sample population constituted fishers and fish farmers. Various sample methods were used for sample selection.

The fishermen constituted the first category of respondents for the study. The list of inland and marine fishing villages was obtained from the data sources of the Department of Fisheries, Kerala State and two villages from each category from South, Central and North Zones of Kerala State were selected. Accordingly, three inland fishing villages namely Vellayani, Thalayazham and Kumbalam and three marine fishing villages namely Ambalapuzha, Chellanam and Vadanappally were selected. In each selected village, households with fishers were identified and 20 respondents were selected for interview using simple random technique. In total, 120 samples were selected through systematic random sampling and data collected directly by interviewing them by using questionnaire. The same procedure was adopted for data collection in inland and marine fishing villages. A 10:2 Ratio for Men:Women was maintained for data collection.

The respondents in second category constitute Fish Farmers. Fisheries development agencies namely Fish Farmers' Development Agency (FFDA) and Agency for Development of Aquaculture, Kerala (ADAK), one each belonging to South, Central and North zones of Kerala namely Alappuzha, Ernakulam and Thrissur were approached for the list of registered fish farmers with address and contact details. Fifty numbers of farmers as respondents were selected at random. Another fifty numbers of 
fish farmers with e-mail address were selected at random from the Archive of Frequently Asked Questions (FAQ) in Kissan Kerala web site at www.kissankerala.net.

Questionnaire prepared in local language was served in person, by Post or by e-mail. In order to make up the deficiency caused by no-response on e-mail/by post, data were collected directly from farmers by visiting Thalayazham and Kumarakom fishing villages and the response rate was maintained at $100 \%$.

\section{FISHERIES INSTITUTIONS}

The State of Kerala has large number of institutions for generation, utilization and dissemination of information devoted to research, education and development in fisheries and allied areas under various organizational streams. In all these institutions, library / documentation/ information centres are the functional base or the agents of information resources and services to its clientele.

Information resources in these institutions sum the information and knowledge repositories in the sector. The conventional sources such as books, journals, theses, reports, microfiche, posters, maps, chart etc and the modern Electronic Information Sources (EIS) such as web pages, Portals, Internet based services, Electronic Thesis and Dissertations (ETDs), Digital Repositories, Digital Archives, audio-visual materials, CDs/DVDs, online databases, e-journals, e-books etc form the collections of the present day Library/Information/Documentation Centre.

\section{EVALUATION OF INFORMATION NEEDS, SOURCES AND SERVICES}

To partner with the patron, studies on library user needs, information needs, etc. are very important to

(a) improve the user experience and make the resources key to their needs,

(b) offer the opportunity to provide the right resource at the right time in right manner, and

(c) create a better match with the expressed needs of the users. The details of the assessment by the primary stakeholders on the information needs, sources and services in the fisheries sector of Kerala are given in the following sections.

\section{PERCEPTIONS ON INFORMATION NEED}

Fish farmers and fishers were asked whether they need information for 
their livelihood activities and asked to rate it on the criteria viz., (1) very essential (2) essential (3) important (4) necessary and (5) not necessary. Seventy four percent (74\%) of fish farmers and twenty six percent $(26 \%)$ of fishers consider information in various formats are very essential for their livelihood activities and in making profit. (Figure 1) Only one percent $(1 \%)$ of farmers and ten percent $(10 \%)$ of fishers consider information not necessary in their farming/fishing activities and profit making. High percentage of perception for information as very essential by fish farmers is because of the biological processing involved in fish farming. They sow and reap and lot of factors are involved for success in their entrepreneurial activities.

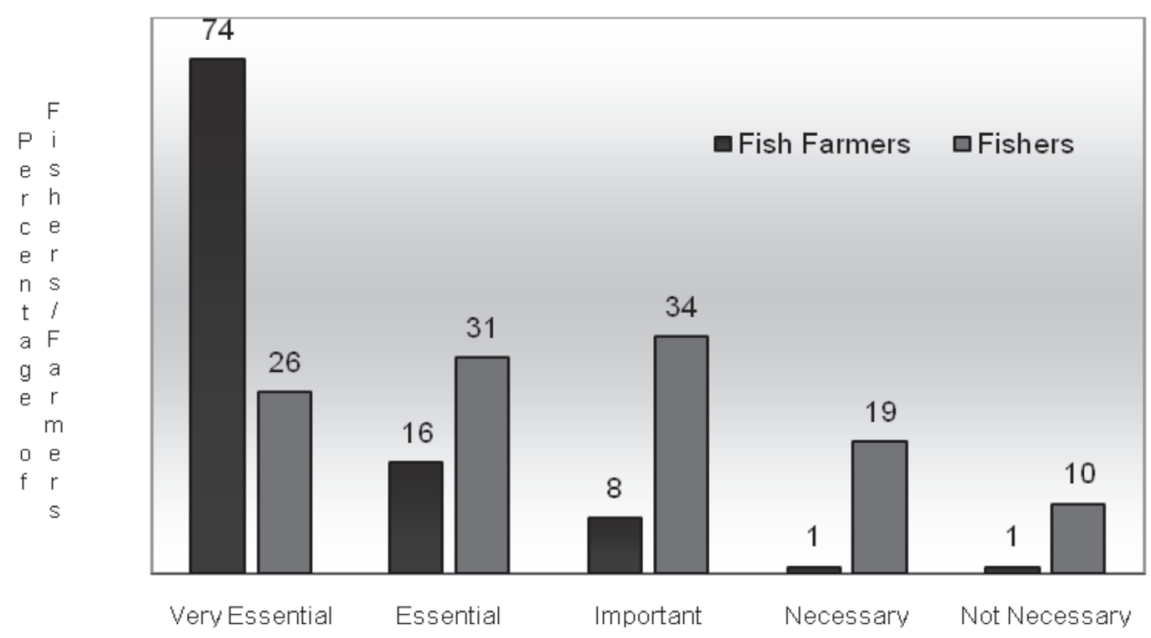

Fig. 1: Perceptions on Need of Information.

In fish farming, the major demand for information caters to small-scale group (56\%) and only $8 \%$ constitute information for large scale fish farming (Fig.2).

Information on small scale followed by homestead fish farming was in need by the farmers. Information needs of fish farmers on the criteria of fish species selection, fish breeding, fish disease and disaster management, farm implements, sustainable fish farming etc were collected and summarised in Figure 3. 


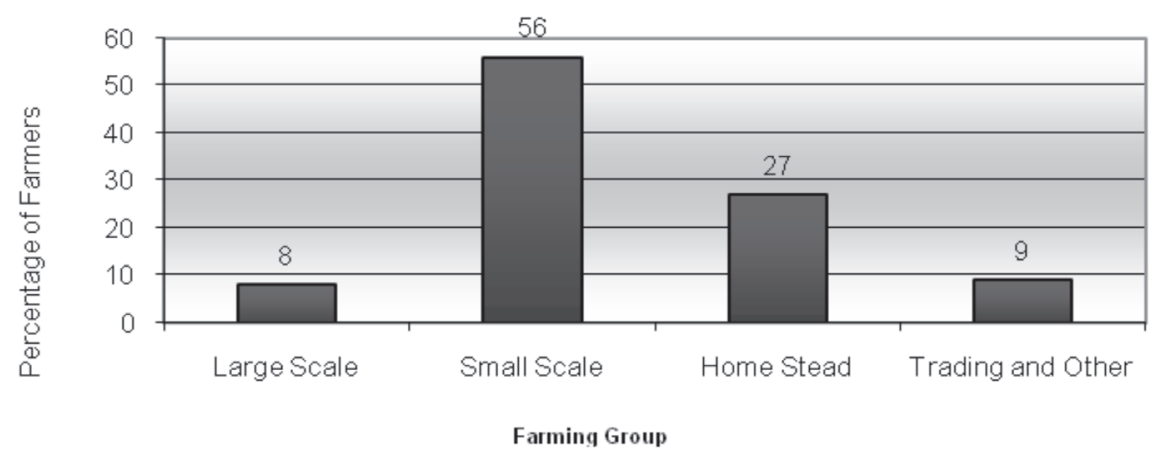

Fig. 2: Information Needs on various Fish Farming groups.

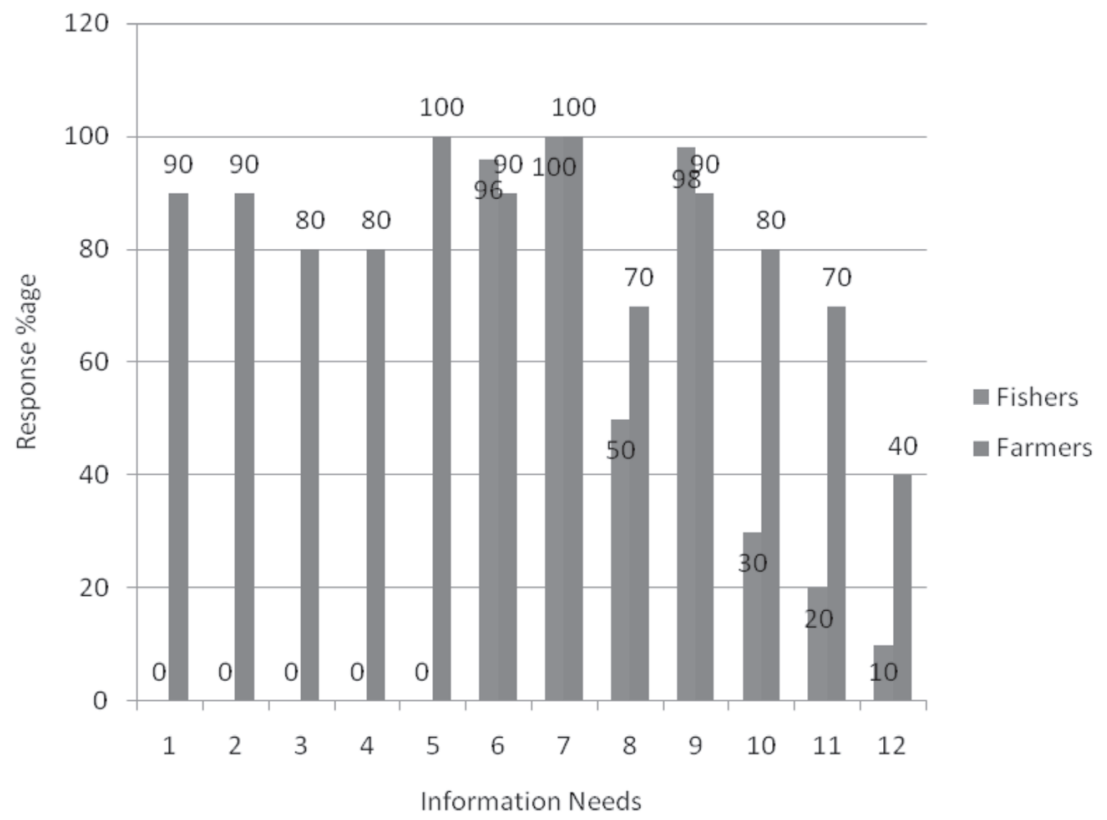

Fig.3: Information Needs on Fishing and Farm Related Activities.

Legend - 1: Seed/Feed Selection \& Suitability; 2: Scheduling of Farm Operations; 3: Fertilizer/Feed/Medicine Application; 4: Breeding/Culture/Rearing; 5: Disease; 6: Weather/Disaster Warning; 7: Market Related; 8: Machines/Implements; 9: Schemes/ Subsidies/Insurance; 10: Responsible farming/fishing; 11: Ancillary/Allied Operations; 12: Other

Summary figure shows that the information requirements of fishers and fish farmers differ. This is necessarily due to differences in their operations. Fish farming is an effort to manage a biological process but 
capture fishery is beyond control. Both categories of respondents are wary of marketing, weather, and subsidy information. Fish farmers are in need of marketing, disease, species, seed, feed, disaster, scheduling of farm operations, and welfare schemes/subsidies/insurance. They needed information, with minor variations on all farm related activities. Knowledge of fish physiology and biology is vital to fish farmers whereas capture fishers function without knowledge of these aspects. However, technologies and knowledge of operation of gears are vital in fish farming as well as in fishing. The fishers and the fish farmers are equally concerned once their product is harvested especially information relating to marketing and other allied operations.

Fish farming (aquaculture) and fishing differs in many aspects. If fishing can be equated to hunting activity, aquaculture is agriculture involving cultivation of fish in a fixed location. Fish, like cattle or sheep, have to be fed and cared for. Like the crop producer, the fish farmer has to be concerned with the growth and timing of the harvest. Fishing entails only harvesting, the rest taken care of by nature itself. The overall findings clearly highlight the deficiencies in information services rendered by concerned agencies in the sector. Need-based and demand-driven information services are deficient in the sector as a whole. The small scale and homestead farming sectors need special attention in this regard.

\section{PERCEPTION ON INFORMATION SOURCES}

The primary stakeholders were asked to rate the sources they rely on for fishery information among conventional, institutional, societal and personal sources of information. Fishers rely on mobile phones (30\%) and other personal ways (20\%) for information. Farmers consider the Internet (20\%), personal ways (14\%) and the libraries (9\%) as source of information. Their perspectives on information source/ media are given in Figure 4. Use of Internet sources was higher among fish farmers in comparison with the fishers. This indicates the need for ICT based certified contents services for the benefit of fish farmers. The sources like information kiosk, Village Knowledge Centre, fish clinic, etc. were not known to the fishers and fish farmers in Kerala.

\section{PERCEPTION ON INFORMATION SERVICES}

The perceptions of the fish farmers and fishers about effectiveness and usefulness of information systems and services in the sector were evaluated on the criteria viz.,(1) very good (2) good (3) satisfactory (4) inferior (5) bad and (6) no rating. Fish farmers and fishers rated the system 


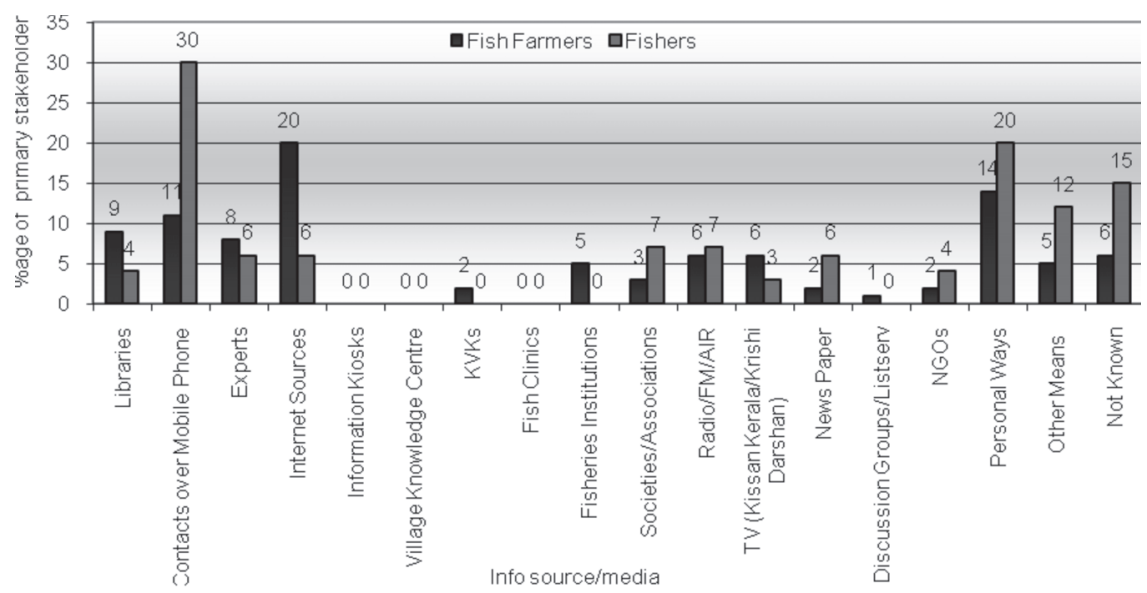

Fig. 4: Information Sources Preferred.

as inferior (32 and 27 percentage) and 32 and 26 percentage as satisfactory, respectively. Majority of fishers could not give ratings as they were unaware about the existence of such services. Figure 5 shows perceptions on usefulness of such services. The findings suggest that upgrades in information services are needed in the sector. The sector also needs a system for barrier free information to the primary stakeholders.

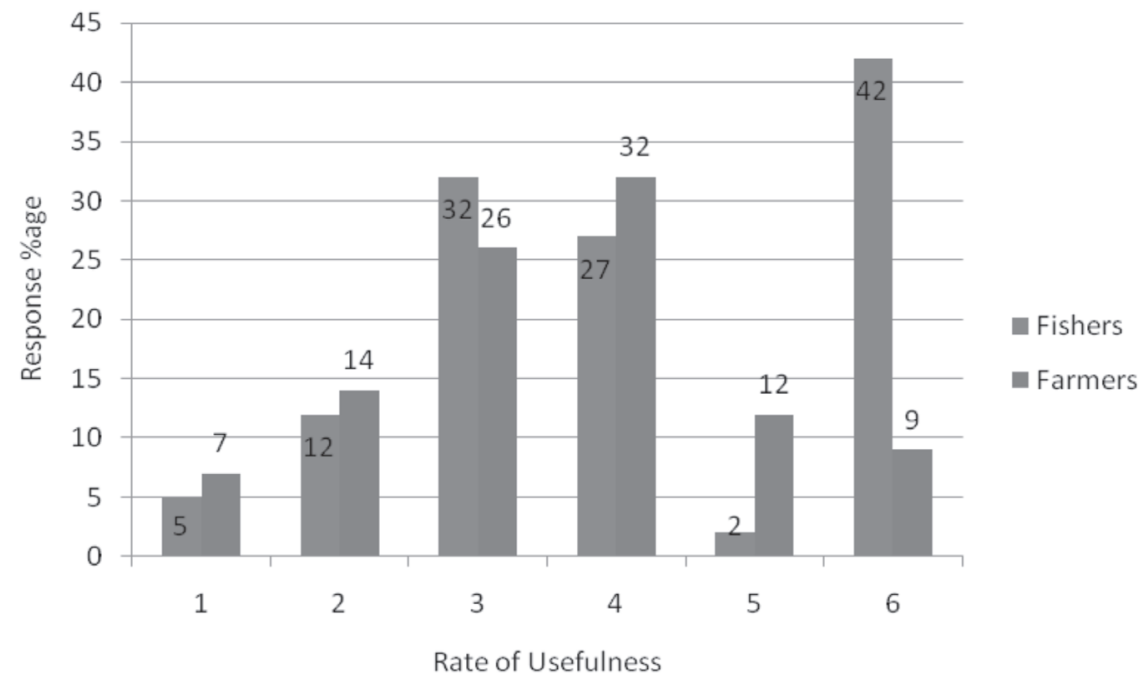

Figure 5: Usefulness of Information Services

Legend : 1: Very Good; 2: Good; 3: Satisfactory; 4: Inferior; 5: bad; 6:No Rating 
Primary stakeholders were asked to render their preferences on institutional facilities for access to information viz., (1) fisheries institution libraries (2) village libraries/ VKCs/ societies/ Akshaya centres; (3) Matsya Bhavans/ Board/ Department offices and (4) NGOs was surveyed. Survey was conducted separately for fish farmers and fishers because the information requirements in the farming operations differ from fishing operations. Figure 6 gives the summary of fish farmers preferences, and Figure 7, preference of fishers.

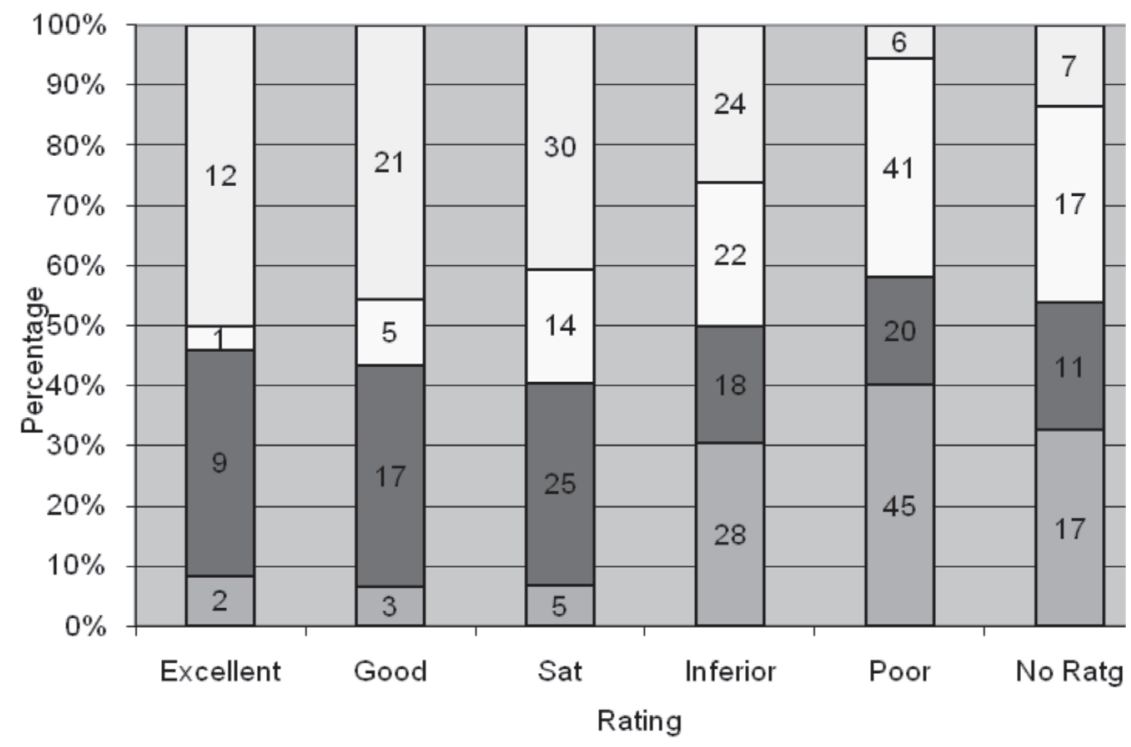

口Fisheries Institution Libraries
$\square$ Village Libraries/VKCs/ Societies/ Akshaya centres
$\square$ Matsya Bhavans/Board/ Dept. Offices
$\square$ NGOs

Fig.6: Preferences of Fish Farmers on institutional facilities for information access.

Figure 6 reveals that village level information centres $(9 \%, 17 \%$ and $25 \%)$ and NGO centres $(12 \%, 21 \%$ and $30 \%)$ are mostly preferred by fish farmers over institutional centres $(2 \%, 3 \%, 5 \% 28 \%, 45 \%$ and so on) and department offices ( $1 \%, 5 \%, 14 \%, 22 \%$ and so on). 


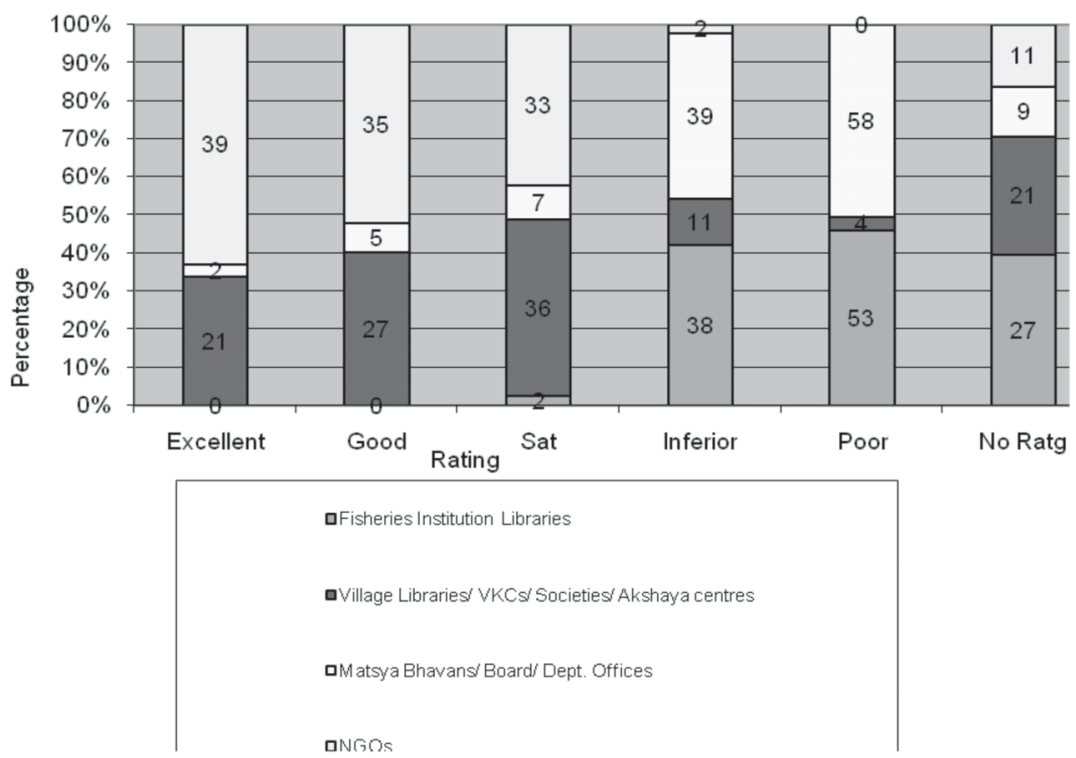

Fig.7: Preferences of Fishers on institutional facilities for information access

Figure 7 reveals that village level information centres $(9 \%, 17 \%$ and $25 \%)$ and NGO centres $(12 \%, 21 \%$ and $30 \%)$ are mostly preferred by fishers over institutional centres $(2 \%, 3 \%, 5 \% 28 \%, 45 \%$ and so on) and department offices $(1 \%, 5 \%, 14 \%, 22 \%$ and so on).

The overall findings suggest that the grass-root level institutions like NGOs, village libraries, primary societies, etc. are preferred by the primary stakeholders over the government offices and institutional libraries. It indicates the need for revamping information services in the government offices and institutions so as to satisfy the needs of the primary stakeholders.

\section{DEFICIENCY IN INFORMATION SERVICES IN THE SECTOR}

Information service needs of the primary stakeholders differ from that of scientists, teachers, researchers and students. Evaluation was done using Mann-Whiteney test to know whether there was any significant difference between two groups viz fish farmers and fishers in respect of their needs for information services deficient thereto. The services needed by the primary stakeholders were categorized as (1) training on new technological information (2) weather warning in mass media/ mobile; (3) simple printed materials in local language on scientific matters (4) single 
window information gateways on fishery related matters (5) accessibility to Help Desk, experts and other sources of information, and (6) accessibility to market / farming/ fishery/ finance/ welfare related information on Internet/ Mobile in local language. The rating criteria for the test were (1) highly needed (2) much needed (3) needed (4) low need (5) not needed, and (6) no rating. The box plot of the test is given as Figure 8.

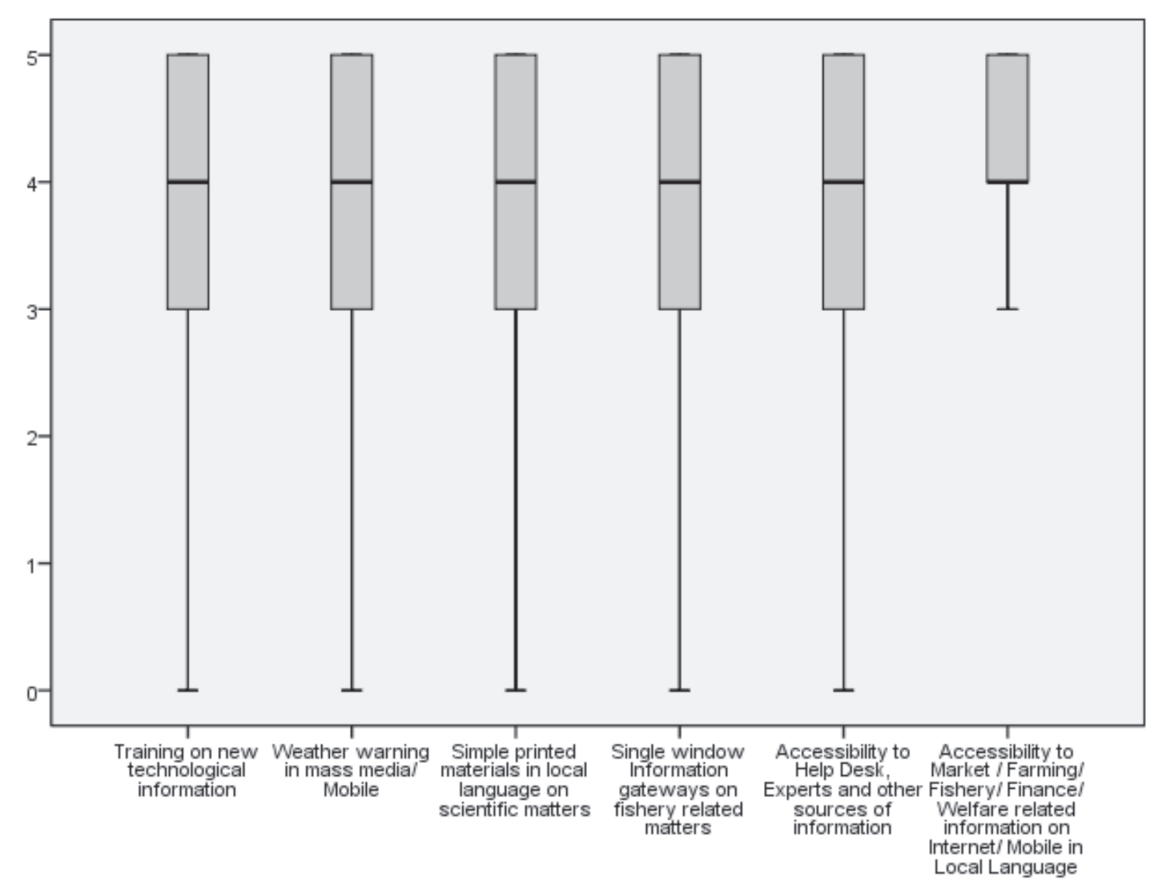

Fig.8: Information Service Needs.

All the categories had median value of 4 . Need for market/farming/ fishery/ finance/ welfare related information on Internet/ mobile in local language was rated precisely by the stakeholders

\section{AWARENESS OF ADVISORY SERVICES}

Awareness of the fish farmers and fishers on various information/ advisory services operational in the sector were evaluated. The result is presented in Figure 9.

Welfare, weather (Ocean State Forecast (OSF)) and Preferred Fishing Zone (PFZ service) of INCOIS and other related information services 


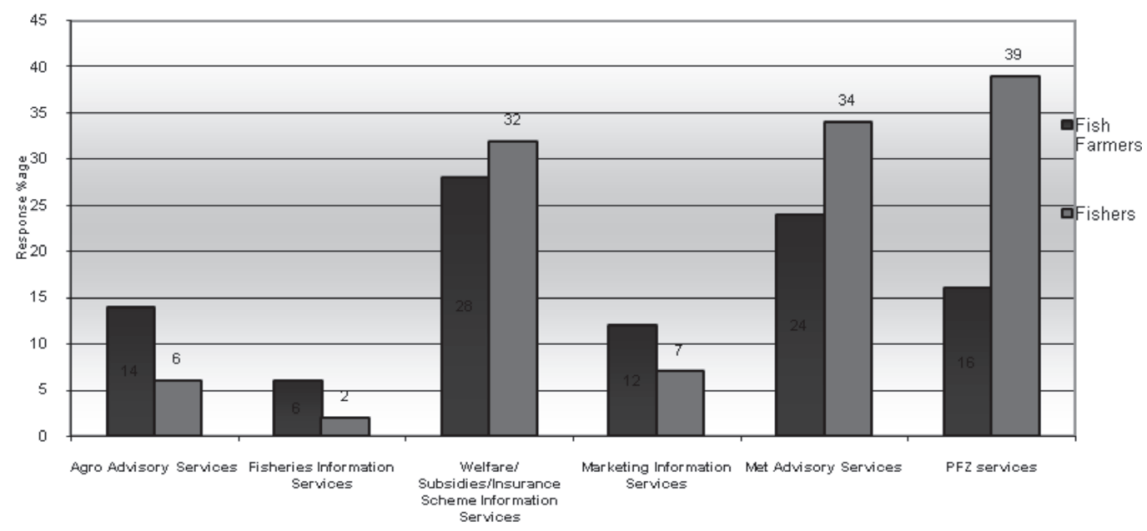

Fig.9: Awareness of Advisory Services.

were known to $30-40 \%$ of fishers surveyed. Welfare and weather information were known to $24 \%$ and $27 \%$ of fish farmers, respectively. Fisheries and marketing related information were found to be low among fish farmers and fishers. It is well known that OSF and PFZ are highly innovative, ICT driven and are disseminated over a wide spectrum of media. Awareness about these services were also high among the stakeholders. It is evident that the communication, media, technology and information contents are to be integrated and harmonized for effective information services.

\section{MEDIA PREFERRED FOR INFORMATION SERVICES}

Media preferred for information services by the fish farmers and the fishers are presented in Figure 10.

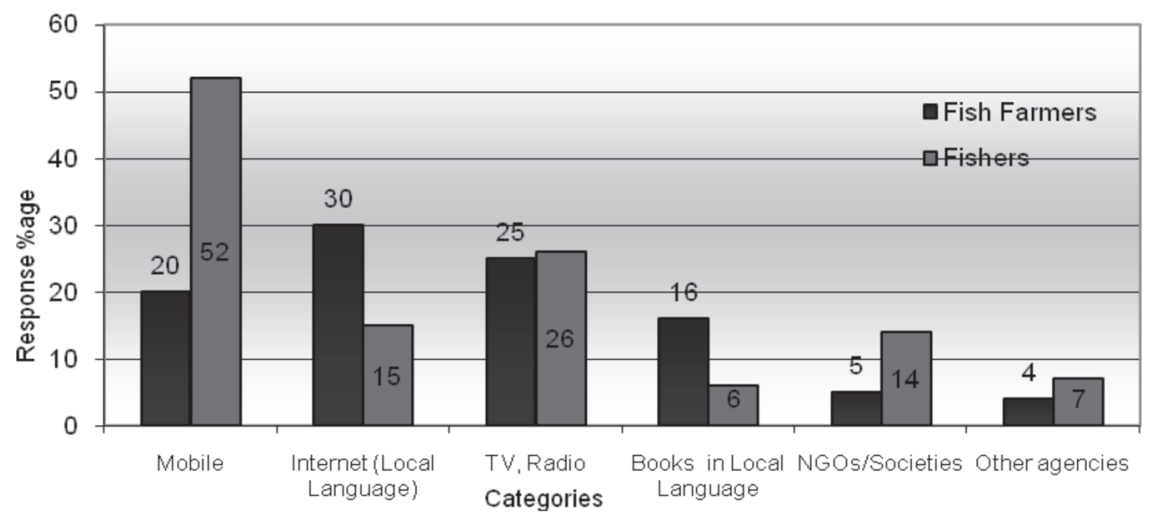

Fig. 10: Media Preferred by farming and fishing communities. 
Mobile phones and Internet were the preferred media. Fishers preferred mobile phones (52\%) and fish farmers preferred Internet based services (32\%). Television and radio were also popular among them. Such media can be used for addressing large number of stake holders, especially during calamities. Media remain important for the proper access and utilization of information services. Mobile based services such as Simple Message Services (SMS), alerts on inclement weather conditions, credit of amount from societies or government welfare funds into the bank account of the farmer, etc. can help them saving time and efforts. Such services can also sensitize them on newer media of information services in the offing.

State government can collaborate with and seek expertise of NGOs in setting up Village Knowledge Centres (VKCs) and other Information Access Centres. The best model in this regard is M S Swaminathan Research Foundation (MSSRF), Chennai which provides information services to the fishing community in selected regions. The DepartmentNGO relations should be promoted in designing and implementing information dissemination services instead of the bureaucratic ridden, non-demand driven; non-diffusion media based; non-absorbent content driven; non-comprehensible language driven information services. An institutional set up is the need of the hour to harmonize various tech-savvy media and information services. The village libraries and primary societies at the grassroots, which collect and serve printed books, pamphlets, etc. can be used as powerful tools for information dissemination. The State Department brings out handbooks and pamphlets on various subjects but it does not reach the grassroots.

\section{CRITICAL ASSESSMENT ON FISHERIES INFORMATION SOURCES AND SERVICES}

Critical assessment on information sources and services offered to the primary stakeholders were evaluated on the criteria viz., (1) no spreading of awareness (2) diverse sources (3) institutional sources non reachable (4) local language disregarded in ICT based services and (5) information services are not user driven and not demand driven and were put to test. Evaluation results are presented in Figure 11.

The analysis shows that information provisions to both categories of primary stakeholders viz., fishers and fish farmers are vulnerable. The vehement expressions are above $50 \%$ on all the criteria put to test. Disregard of local language in ICT based services scored the highest at 

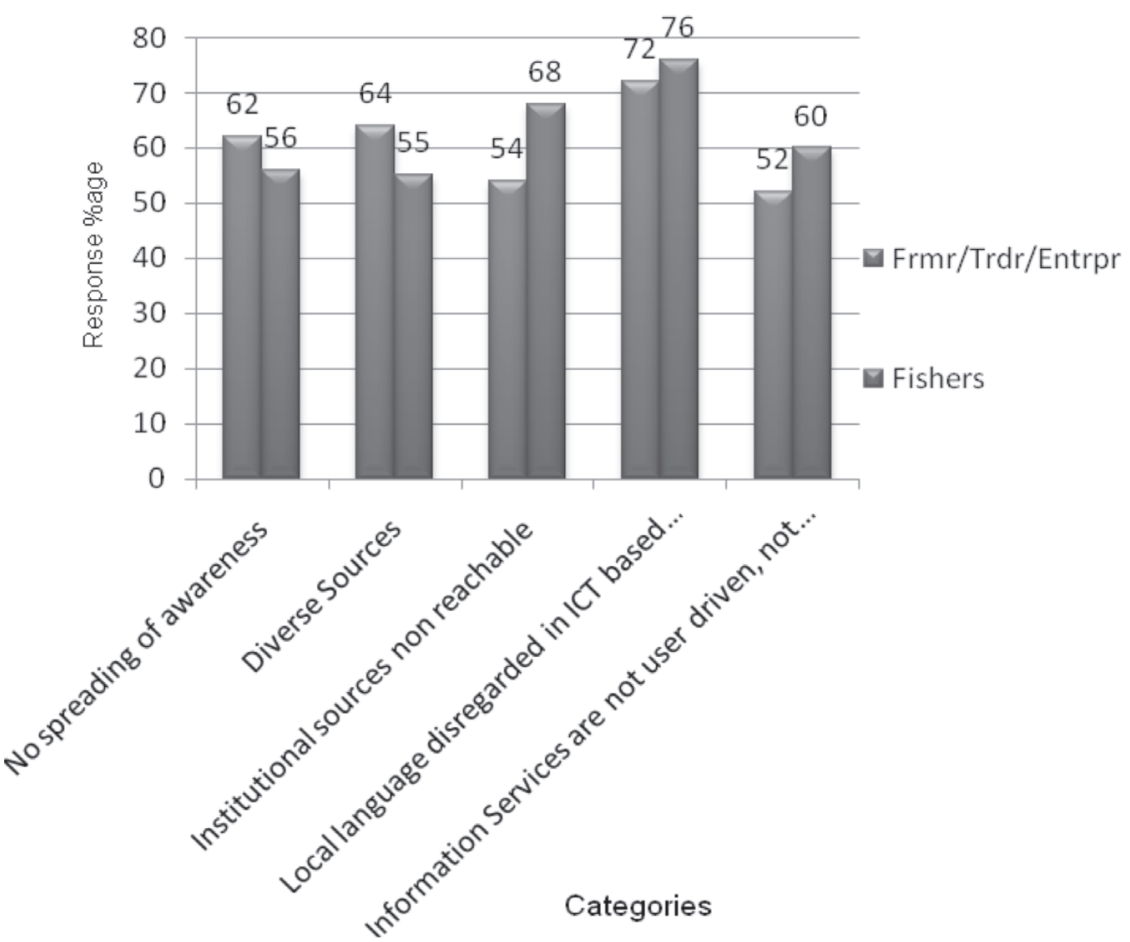

Fig.11: Critical Assessment on Information Sources and Services

$72 \%$ and $76 \%$ by fish farmers and fishers respectively. Diverse sources, non reachable institutions, lack of awareness on sources, scant regard to the primary stakeholders in the information services designed, etc. are other issues in the sector. The results suggest that a fresh and an integrated view of fisheries information services is needed in the sector for its effectiveness and efficiency to be useful to the primary stakeholders.

\section{FINDINGS AND RECOMMENDATION}

Digital and other electronic technologies are transforming our economies, societies and people's lives. Technology has had a profound impact on the information and communication activities that have always been central to sustainable development. ICT based Agricultural Information Services presently in vague do not amply cover fisheries sector. Impact of the ongoing information service programmes in farming sector need to be studied in detail and if found useful, similar services should suitably be extended to fisheries sector. 
Mobile phones are the powerful hand held computing machines which can provide means for faster communication of information on fisheries practices, ocean warning, weather information, market prices and, water specific and region specific fisheries information. However, services based on mobile telephony are not common in fisheries sector.

Library and information systems can play crucial roles for delivery of services because libraries are the important tool or agencies for information delivery and for guiding users through the maze of complex sources of information. Libraries should perform information sharing activities that leads to spread of information and knowledge for the development of the primary stakeholders and fisheries sector as a whole.

Appropriate communication and networking methods enable better reach to target audiences including improved access to print and electronic material in local languages. Use of media such as radio, television, easyto-understand and well-illustrated forms of information, interactive platforms to exchange experience, dedicated training workshops, etc. are the popular methods in this direction. However, the existing systems in the sector are conventional and moribund on many grounds.

Kissan Kerala, the ICT enabled service operational in farming sector offers new dimensions in providing information services. The dynamic information provision is absent in even in the Home pages of the Department of Fisheries of Kerala State. There is need for extending the potentials of Cyber systems and implementing information exchange programmes optimally in fisheries sector for better utilization of information resources.

Enterprises in fisheries sector such as fishing and fish farming (aquaculture) should be seen not only as a technical and biological innovation, but also as a socio-economic enterprise that requires the same kind of social analysis, services and systems as any other production system. The findings may prompt policy makers to introduce grass root level service centres and media-driven information services for optimum dissemination of fisheries information to the stakeholders.

Fisheries and aquaculture being multi-disciplinary in nature, organization of an information system needs careful planning and implementation. An information system dedicated to the fisheries sector in the State has to organize data, information and knowledge in a cohesive manner. It should provide a single window access to information to meet 
the needs of the end users and stakeholders. The dynamic trends and advancements in ICT make it possible for the free flow and real time transfer of information. Larger participation of LIS professionals, as in any knowledge management system, needs to be adopted in fisheries sector also for its success.

\section{CONCLUSION}

Equal opportunity to access information is as important for the fishing community as for the research or business patron in fisheries sector. The universal access to information with backing of ICT in all spheres of human activities is a well-accepted norm. Web sites, gateways and portals are being created for barrier-free flow of information. Improvement in electronic connectivity and digitization of information are the prerequisites for flow of digital information that is taking place everywhere. As technology is ready, an information system dedicated to the fisheries sector, not only in Kerala, but also whole India, ensuring equitable access to fisheries information is needed for the development of fisheries sector.

\section{REFERENCES}

1 YELLEN ( JE) et al, A Middle Stone-age Worked Bone Industry from Katanda, Upper Semliki Valley, Zaire, Science, 268 (1995) 553-556.

2 SILAS (EG), Ed, Indian Fisheries 1947-77, (CMFRI; Cochin), 1977.

3 PILLAI ( NGK) and KATIHA ( PK). Evolution of Fisheries and Aquaculture in India, (CMFRI; Cochin), 2004

4 DEHADRAI ( PV). Women at the Centre Stage for Socio-Economic Change in Fishing Community. In: Ninawe AS and Diwan AD, (Eds). Women Empowerment in Fisheries, (Narendra Publishing; New Delhi) 2005.

5 AGARWAL ( SC). History of Indian Fishery,(Daya Publishing; New Delhi), 2006.

6 GOVERNMENT OF INDIA, Fisheries. [Online]. Available at:http://india.gov.in /sectors/agriculture/fisheries.php. (Accessed on 12 Apr 2012)

7 GOVERNMENT OF KERALA. Fisheries Department. [Online] Available at: http://www.fisheries.kerala.gov.in/ (Accessed on 10 Dec 2012)

8 GOVERNMENT OF KERALA, Kerala Inland Fisheries Statistics, (Department of Fisheries; Trivandrum), 2009.

9 GOVERNMENT OF KERALA, Kerala Marine Fisheries Statistics, (Department of Fisheries; Trivandrum), 2010.

10 GOVERNMENT OF KERALA, Human Development Report 2005, (Kerala State 
Planning Board and Centre for Development Studies; Trivandrum), 2006.

11 GHOSH (Sanjeev D). Data Needs and Gaps in Kerala Fisheries, In: Ramachanadran Nair and Rajan, J.B. (Eds). Kerala Fisheries: Exploring Data Needs for Resource Management, (Kerala Institute for Environment and Development; Trivandrum), 2007. 